\title{
PENGARUH SENAM NIFAS TERHADAP INVOLUSI UTERUS PADA IBU POST PARTUM PRIMIPARA PERVAGINAM DI KLINIK BERSALIN TUTUN SEHATI TANJUNG MORAWA TAHUN 2013
}

\author{
Nurlama Siregar \\ Jurusan Keperawatan Medan
}

\begin{abstract}
Abstrak
Senam nifas merupakan latihan jasmani yang berfungsi untuk mengembalikan kondisi kesehatan, untuk mempercepat penyembuhan, mencegah timbulnya komplikasi, memulihkan dan memperbaiki regangan pada otot-otot setelah kehamilan, terutama pada otot-otot bagian punggung, dasar panggul, dan perut. Tujuan dari penelitian ini adalah untuk mengetahui apakah ada pengaruh senam nifas terhadap involusi uterus pada ibu post partum pervaginam hari 1-3 di Klinik Bersalin Tutun Sehati Tanjung Morawa. Jenis penelitian yang digunakan adalah quasi experimental dengan metode one group pre test and post test design. Teknik pengambilan sampel dalam penelitian ini menggunakan purposive sampling, yaitu cara untuk mendapatkan besar sampel dengan memilih diantara populasi sesuai dengan yang dikehendaki oleh peneliti, jumlah sampel dalam penelitian ini sebanyak 30 orang dimana terbagi alas 2 kelompok yaitu 15 orang sebagal kelompok intervensi dan 15 orang sebagai kelompok kontrol. Instrumen penelitian yang digunakan berupa Kuesioner Data Demografi (KDD) dan lembar pemeriksaan. Dari hasil penelitian ini, setelah ibu post partum melakukan senam nifas selama 3 hari dengan gerakan yang benar, rata-rata penurunan tinggi fundus uterus yaitu $5 \mathrm{~cm}$ per hari. Sedangkan penurunan tinggi fundus, uterus pada ibu post partum yang tidak melakukan senam nifas rata-rata $2 \mathrm{~cm}$ per hari. Dari hasil perhitungan dengan menggunakan uji-t yaitu Independent sampel T-Test didapatkan hasil t hitung 11,02 > t tabel 1,70. Ini berarti bahwa Ho ditolak yang menunjukkan bahwa ada pengaruh senam nifas terhadap involusi uterus pada ibu post partum primipara pervaginam hari 1-3 di Klinik Bersalin Tutun Sehati Tanjung Morawa. Diharapkan hasil penelitian ini dapat diterapkan oleh Klinik Bersalin Tutun Sehati Tanjung Morawa dengan memberikan motivasi kepada ibu-ibu post partum untuk melaksanakan senam nifas yang bermanfaat dalam proses pemulihan diri pasca partus.
\end{abstract}

Kata kunci : Senam Nifas, Involusi Uterus, Ibu Post Partum Pervaginam

\section{PENDAHULUAN}

Dalam perhitungan statistik populasi penduduk dunia PBB, bayi yang lahir pada hari Senin, 31 Oktober 2011 adalah warga dunia yang ke tujuh miliar. Hal itu terungkap dari sebuah laporan Kondisi Populasi Dunia 2011 yang dikeluarkan PBB. Laporan tersebut memandang tonggak populasi tujuh miliar sebagai tanda kelangsungan hidup lebih lama dan peningkatan tingkat kelahiran bayi yang hidup. Negaranegara penyumbang penduduk bumi terbesar dan tercepat ada di Negara-negara berkembang kawasan Asia dan Afrika seperti India, Pakistan, Tiongkok, Bangladesh, Nigeria, Ethiophia. Dari 7 miliar manusia dunia, didominasi penduduk Asia, dengan jumlah yang mencapai 4,2 miliar (The Children Indonesia, 2011).

Disamping angka pertumbuhan penduduk yang makin tinggi, angka kematian, khususnya angka kematian ibu bersalin juga masih tinggi. Berdasarkan penelitian Woman Research Institute, angka kematian ibu melahirkan saat ini 307 per 100.000 kelahiran hidup. Menurut Menteri Koordinator Kesejahteraan Rakyat Agung Laksono, angka kematian ibu di
Indonesia yang mencapai 128 dari 100.000 kelahiran hidup, dinilai masih terlalu tinggi khususnya di kalangan negara-negara ASEAN.

Disamping masalah di atas, rendahnya kesadaran masyarakat tentang kesehatan ibu nifas juga menjadi faktor tertentu angka kematian, meskipun masih banyak faktor yang harus diperhatikan untuk menangani masalah ini. Penyebab kematian ibu adalah perdarahan, eklampsia atau gangguan akibat tekanan darah tinggi saat kehamilan, partus lama, komplikasi aborsi, dan infeksi. perdarahan biasanya tidak bisa diperkirakan dan terjadi secara mendadak bertanggung jawab atas 28\% kematian ibu. Sebagian besar kasus perdarahan dalam masa nifas terjadi karena retensio plasenta dan atonia uteri (Departemen Kesehatan RI, 2003).

Menurut Dr. Firansisca dari Fakultas Kedokteran Universitas Wijaya Kusuma Surabaya, banyak faktor potensial yang dapat menyebabkan hemorrhage post partum (perdarahan post partum). Faktor-faktor yang menyebabkan hemorrhage postpartum adalah atonia uteri, perlukaan jalan lahir, retensio plasenta, atau kelainan pembekuan darah. 
Menurut Bobak (2004) penyebab perdarahan setelah melahirkan yang paling sering ialah atonia uteri yaitu kegagalan otot rahim untuk berkontraksi dengan kuat. Atonia uteri adalah suatu keadaan dimana uterus gagal untuk berkontraksi dan mengecil sesudah janin keluar dari rahim. Atonia uteri terjadi ketika myometrium. tidak berkontraksi. Salah satu cara yang dapat dilakukan untuk mencegah terjadinya perdarahan pasca persalinan adalah dengan merangsang kontraksi miometrium maka salah satu upava yang dilakukan adalah senam nifas (Depkes, RI, 2003).

Namun faktanya, para ibu pasca melahirkan takut melakukan banyak gerakan, sang ibu khawatir gerakan-gerakan yang akan dilakukannya akan menimbulkan dampak yang tidak diinginkan. Padahal, apabila ibu bersalin melakukan ambulasi dini, itu bisa memperlancar terjadinya involusi uterus. Dan pada umumnya wanita yang telah melahirkan sering mengeluh bagian tubuhnya melar, bahkan kondisi tubuhnya kurang prima akibat letih dan tegang. Sementara peredaran darah dan pernafasan belum kembali normal, sehingga untuk membantu mengembalikan tubuh ke bentuk dan kondisi semula harus melakukan senam nifas yang teratur (Jurnal Kesehatan FORIKES, 2011).

Ada beberapa faktor yang mempengaruhi involusi uterus. Faktor-faktor tersebut meliputi senam nifas, mobilisasi dini post partum, menyusui dini, gizi, psikologis, faktor usia dan paritas (Widianti, 2010).

Menurut Huliana (2005) salah satu faktor yang mempercepat involusi adalah senam nifas yaitu bentuk ambulansi dini pada ibu-ibu nifas yang salah satu tujuannya untuk memperlancar proses involusi, sedangkan ketidaklancaran proses involusi dapat berakibat buruk pada ibu nifas seperti terjadi perdarahan yang bersifat lanjut dan kelancaran proses involusi. Manfaat senam nifas diantaranya adalah membantu penyembuhan rahim, perut, dan otot pinggul yang mengalami trauma serta mempercepat kembalinya bagian-bagian tersebut ke bentuk normal, membantu menormalkan sendi-sendi yang menjadi longgar akibat kehamilan dan persalinan, serta mencegah pelemahan dan peregangan lebih lanjut. Latihan senam nifas dapat segera dimulai dalam waktu 24 jam setelah melahirkan lalu secara teratur setiap hari (Bobak, 2004).

Namun perlu diketahui bentuk latihan senam nifas ibu pasta melahirkan normal dengan yang melahirkan dengan sesar tidak sama. Pada ibu yang melahirkan dengan cara sesar beberapa jam setelah keluar kamar operasi, latihan pernafasan dilakukan untuk mempercepat penyembuhan luka. Sementara latihan untuk mengencangkan otot perut dan melancarkan sirkulasi darah dibagian tungkai dapat dilakukan 2-3 hari setelah ibu dapat bangun dari tempat tidur. Sedangkan pada persalinan normal, bila keadaan ibu sudah cukup baik, maka semua gerakan senam nifas dapat dilakukan (Widianti, 2010).

Penurunan ukuran uterus yang cepat itu dicerminkan oleh perubahan lokasi uterus ketika turun keluar dari abdomen dan kembah menjadi organ pelviks. Segera setelah proses persalinan puncak fundus kira-kira dua pertiga hingga tiga perempat dari jalan atas diantara simfisis pubis dan umbilikus. Kemudian naik ke tingkat umbilikus dalam beberapa jam dan bertahan hingga dua atau dua hari dan kemudian secara berangsur-angsur turun ke pelviks yang secara abdominal tidak dapat terpalpasi di atas simfisis setelah sepuluh hari (Widianti, 2010).

Namun adakalanya dijumpai kegagalan uterus untuk kembali pada keadaan tidak hamil atau disebut dengan subinvolusi. Penyebab subinvolusi yang paling sering ialah tertahannya fragmen plansenta dan infeksi (Bobak, 2004).

Hasil berupa survei secara acak tentang efek senam nifas pada 1003 wanita Amerika mengaku setelah mengikuti program senam nifas dengan latihan yang teratur mengalami pengerutan pada rahim yang lebih kuat, selain itu juga mengalami penurunan pada berat badan selama enam minggu setelah melahirkan. Dan dalam studi dari 1432 ibu nifas di Swedia yang melakukan senam nifas ditemukan bahwa mayoritas $71 \%$ wanita tersebut mengalami metabolisme tubuh yang lancar, dan pemulihan fisik yang lebih cepat (Larson, 2002).

Hasil penelitian yang dilakukan oleh Yuniasih Purwaningrum (2011) tentang Pengaruh Senam Nifas Kecepatan Penurunan Tinggi Fundus Uteri pada Ibu Post Partuni Primipara Hari 1-5 di Puskesmas Mergangsan Malang didapatkan hasil pada kelompok intervensi sebelum dilakukan senam nifas rata-rata TFU adalah 11,75 cm dengan standar deviasi $0,67 \mathrm{~cm}$. setelah dilakukan senam nifas diperoleh rata-rata TFU adalah 7,35 cm dengan standar deviasi $0,67 \mathrm{~cm}$. Nilai rata-rata perbedaan antara pengukuran pertama dan pengukuran kedua adalah $4,4 \mathrm{~cm}$ dengan standar, deviasi 10,67 cm. Maka dapat disimpulkan ada pengaruh senam nifas terhadap invulusi uterus, yaitu perbedaan yang signifikan pada TFU sebelum dan setelah dilakukan senam nifas.

Berdasarkan survei pendahuluan yang dilakukan peneliti di Klinik Bersalin Tutun Sehati Tanjung Morawa pada bulan Februari 2013 belum pernah diadakan senam nifas. Pada umumnya masyarakat/ibu nifas tidak melaksanakan senam nifas, hal ini dikarenakan ibu nifas belum mengetahui tentang senam nifas dan tidak menyadari bahwa dengan senam nifas (aktifitas fisik) akan mempengaruhi kebutuhan. otot akan oksigen, aliran darah menjadi lancar sehigga dapat membantu proses pemulihan kesehatan setelah melahirkan. Menurut Bidan yang bekerja di Klinik tersebut, para ibu nifas tidak sempat melakukan senam nifas karena kesibukan sehari-hari sehingga ibu nifas melupakan kesehatannya.

Hal tersebut di ataslah yang membuat penulis tertarik untuk melakukan penelitian tentang "Pengaruh Senam Nifas terhadap Involusi Uterus pada Ibu Post Partum Primipara Pervaginam di Klinik Bersalin Tutun Sehati Tanjung Morawa Medan Tahun 2013”. 


\section{Perumusan Masalah}

Berdasarkan latar belakang di atas maka rumusan masalah penelitian ini adalah apakah ada Pengaruh Senam Nifas terhadap Involusi Uterus pada Ibu Post Partum Primipara Pervaginam di Klinik Bersalin Tutun Sehati Tanjung Morawa?

\section{Tujuan Umum}

Tujuan umum dari penelitian ini adalah untuk mengetahui pengaruh senam nifas terhadap involusi uterus pada ibu post partum primipara pervaginam hari 1-3 di Klinik Bersalin Tutun Sehati Tanjung Morawa Medan.

\section{Tujuan Khusus}

1. Untuk mengidentifikasi involusi uterus sebelum melaksanakan senam nifas pada ibu post partum primipara pervaginam hari 1-3 di Klinik Bersalin Tutun Sehati Tanjung Morawa Medan.

2. Untuk mengidentifikasi involusi uterus sesudah melaksanakan senam nifas pada ibu post partum primipara pervaginam hari 1-3 di Klinik Bersalin Tutun Sehati Tanjung Morawa Medan.

3. Untuk menguji pengaruh senam nifas terhadap involusi uterus pada ibu post partum primipara pervaginam hari 1-3 di Klinik Bersalin Tutun Sehati Tanjung Morawa Medan.

\section{Manfaat Penelitian}

1. Bagi Peneliti. Manfaat penelitian ini bagi peneliti adalah untuk menambah pengetahuan dan pengalaman tentang Pengaruh Senam Nifas Terhadap Involusi Uterus

2. Bagi Ibu-Ibu Post Partum. Manfaat penelitian ini bagi responden adalah dapat meningkatkan pengetahuannya pentingnya senam nifas selama masa nifas untuk mempercepat pemulihan uterusnya ke kondisi sebelum hamil

3. Bagi Institusi Pendidikan. Sebagai bahan masukan dan informasi dalam mengembangkan pendidikan keperawatan maternitas

4. Bagi Peneliti Selanjutnya. Manfaat penelitian ini bagi peneliti selanjutnya dapat dijadikan sebagai data awal ataupun data tambahan untuk mengembangkan penelitian selanjutnya.

\section{Hipotesis Penelitian}

Hipotesis penelitian ini adalah ada pengaruh senam nifas terhadap involusi uterus pada ibu post primipara partum pervaginam hari 1-3 di Klinik Bersalin Tutun Sehati Tanjung Morawa Medan.

\section{Metode Penelitian}

Penelitian ini menggunakan pendekatan kuantitatif dengan menggunakan desain quasi experimental menggunakan satu kelompok kontrol dengan metode two group pre test and post test design.

Peneliti menggunakan dua kelompok, dimana satu kelompok sebagai kelompok intervensi dan satu kelompok sebagai kelompok kontrol atau pembanding.
Peneliti membuat perlakuan terhadap kelompok intervensi dan melakukan pengukuran sebelum dan sesudah dilaksanakannya intervensi.

Penelitian ini telah dilaksanakan di Klinik Bersalin Tutun Sehati Tanjung Morawa Medan.

Penelitian ini telah dilaksanakan selama tiga bulan yakni April sampai Juni 2013.

Populasi penelitian adalah sekumpulan unit penelitian. Populasi dalam penelitian ini adalah seluruh ibu-ibu post partum primipara pervaginam di Klinik Bersalin Tutun Sehati Tanjung Morawa Medan, dimana rata-rata jumlah ibu bersalin sebanyak 30 orang setiap bulan.

Sampel terdiri dari ibu-ibu post partum yang bersalin di Klinik Bersalin Tutun Sehati Tanjung Morawa Medan selama penelitian dilakukan yang dibagi dua menjadi kelompok intervensi (ibu yang melakukan senam nifas) sebanyak 15 orang dan kelompok kontrol (ibu yang tidak melakukan senam nifas) sebanyak 15 orang.

Teknik pengambilan sampel menggunakan purposive saniphng. Kriteria sampel untuk kelompok intervensi sama dengan kriteria sampel untuk kelompok kontrol. Jumlah masing-masing didapatkan pada saat penelitian dilakukan.

\section{Aspek Pengukuran}

Aspek pengukuran pada involusi uterus dilakukan dengan mengukur penurunan tinggi fundus uterus menggunakan pita meter. Hasil pengukuran ditulis dalam lembar pemeriksaan menggunakan Skala ratio.

Pengukuran dilakukan sebanyak 4 kali, pengukuran pertama sebelum dilakukan senam nifas, selanjutnya pengukuran kedua dilakukan setelah melakukan senam nifas pada hari pertama, pengukuran ketiga dilakukan setelah melakukan senam nifas pada hari pengukuran keempat dilakukan setelah melakukan senam nifas pada hari ketiga. Lalu hasil pengukuran kelompok intcrvensi dibandingkan dengan kelompok kontrol yaitu dengan membandingkan hasil rata-rata tinggi fundus uterus pretest andposttest masing-masing kelompok untuk mengetahui pengaruh senam nifas terhadap involusi uterus pada ibu post partum pervaginam hari 1-3.

\section{Teknik Pengolahan Data}

1. Editing : melakukan pemeriksaan atau pengeeekan data yang sudah dikumpulkan.

2. Coding : memberi kode (angka/tanda) pada setiap pernyataan dari jawaban

3. Tabulating : mempermudah pengolahan dan analisa data serta pengambilan kesimpulan, maka data dimasukkan ke dalam tabel.

\section{Teknik Analisa Data}

Setelah semua data dalam kuesioner dikumpulkan, data dianalisa dengan menggunakan teknik analisa kuantitatif. Data diolah dan disajikan dalam bentuk tabel distribusi frekuensi yang memberikan gambaran tentang data demografi 
responden.

Untuk melihat pengaruh senam nifas terhadap involusi uterus pada ibu post partum pervaginam hari 1-3, peneliti melakukan pengujian dengan menggunakan uji-t yaitu Independent Sampel T-Test sebelum intervensi dan sesudah intervensi, dimana, peneliti membandingkan involusi uterus sebelum intervensi, involusi uterus sesudah intervensi, dan perbedaan kecepatan involusi uterus pada kelompok intervensi dengan kelompok kontrol atau pembanding. Menurut Arikunto (2010) secara umum, pola penelitian dilakukan terhadap dua kelompok, yang satu merupakan kelompok intervensi dan kelompok kontrol atau kelompok pembanding yang tidak dikenai perlakuan. Setelah selesai dilaksanakan intervensi maka hasil kedua kelompok diolah dengan membandingkan kedua mean. Untuk sampel random bebas, pengujian perbedaan mean dihitung dengan rumus $t$-test sebagi berikut:

$$
\mathrm{t}_{\text {hitung }}=\frac{M x-M y}{\sqrt{\left(\frac{\sum x^{2}+\sum y^{2}}{N_{x}+N_{y}-2}\right)}\left(\frac{1}{N_{x}}+\frac{1}{N_{y}}\right)}
$$

Keterangan :

$\mathrm{M}_{\mathrm{x}} \quad$ = nilai rata-rata hasil kelompok 1

$\mathrm{M}_{\mathrm{y}} \quad$ = nilai rata-rata hasil kelompok 2

$\mathrm{x}=$ deviasi setiap nilai $\mathrm{x}_{2}$ dan $\mathrm{x}_{1}$

$\mathrm{y} \quad=$ deviasi setiap nilai $\mathrm{y}_{2}$ dan yang

$\mathrm{N} \quad=$ jumlah sampel

Dimana :

$\Sigma \mathrm{x}^{2}$ dapat diperoleh dari $\Sigma \mathrm{x}^{2}-\frac{(\Sigma x)^{2}}{N}$ dan

$\Sigma \mathrm{y}^{2}$ dapat diperoleh dari $\Sigma \mathrm{y}^{2}-\frac{\left(\sum x y\right)^{2}}{N}$

Untuk melihat hasil kemaknaan perhitungan statistik digunakan derajat kemaknaan $\alpha=0,05$ (95\% confidence level). Jika hasil perhitungan t hitung lebih besar daripada $\mathrm{t}$ tabel, maka secara statistik H0 ditolak berarti ada pengaruh senam nifas terhadap involusi uterus pada ibu post partum pervaginam hari 1-3 sebaliknya jika $\mathrm{t}$ tabel lebih besar daripada $\mathrm{t}$ hitung maka HO diterima atau tidak ada pengaruh, senam nifas terhadap involusi uterus pada ibu post partum pervaginam hari 1-3.

\section{HASIL PENELITIAN}

Karakteristik Responden

Tabel 1. Distribusi Frekuensi Umur, Suku, Pendidikan dan Pekerjaan Ibu Post Partum Primipara Pervaginam yang Senam Nifas di Klinik Bersalin Tutun Sehati Tanjung Morawa Medan Tahun 2013

\begin{tabular}{llcc}
\hline No & Umur & $\mathbf{f}$ & $\mathbf{\%}$ \\
\hline 1 & $20-25$ tahun & 12 & 80 \\
2 & $26-30$ tahun & 3 & 20 \\
\hline & Jumlah & $\mathbf{1 5}$ & $\mathbf{1 0 0}$ \\
\hline No & Suku & $\mathbf{f}$ & \% \\
1 & Melayu & 4 & 25,0 \\
2 & Jawa & 11 & 75,0 \\
\hline & Jumlah & $\mathbf{1 5}$ & $\mathbf{1 0 0}$ \\
\hline No & Pendidikan & $\mathbf{f}$ & $\mathbf{\%}$ \\
1 & SMP & 6 & 37,5 \\
2 & SMA & 9 & 62,5 \\
\hline & Jumlah & $\mathbf{1 5}$ & $\mathbf{1 0 0}$ \\
\hline No & Pekerjaan & $\mathbf{f}$ & $\mathbf{\%}$ \\
1 & Tidak bekerja & 9 & 56,0 \\
2 & Wiraswasta & 3 & 17,0 \\
3 & Petani & 3 & 17,0 \\
\hline & Jumlah & $\mathbf{1 5}$ & $\mathbf{1 0 0}$ \\
\hline
\end{tabular}

Berdasarkan tabel di atas dapat diketahui bahwa responden terbesar berada pada kelompok umur 20-25 tahun sebanyak 13 orang $(80,0 \%)$, umur 2630 tahun sebanyak 2 orang (20,0\%). Suku responden terbesar pada kelompok ibu yang senam nifas yaitu suku Jawa sebanyak 11 orang $(75,0 \%)$, suku Melayu sebanyak 4 orang $(25,0 \%)$. Pendidikan responden terbesar berlatar belakang pendidikan SMA sebanyak 9 orang $(62,5 \%)$, kemudian pendidikan SMP sebanyak 6 orang $(37,5 \%)$ dan pekerjaan responden terbesar merupakan ibu rumah tangga atau tidak bekerja sebanyak 9 orang $(56,0 \%)$, kemudian bekerja sebagai wiraswasta sebanyak 3 orang $(17,0 \%)$, bekerja sebagai petani sebanyak 3 orang $(17,0 \%)$.

Pengaruh Senam Nifas terhadap Involusi Uterus pada Ibu Post Partum Primipara Pervaginam di Klinik Bersalin Tutun Sehati Tanjung Morawa Tahun 2013

\begin{tabular}{|c|c|c|c|c|}
\hline \multicolumn{5}{|c|}{ Kelompok Intervensi (Tinggi Fundus Uterus (cm) } \\
\hline Responden & Pre-test $\left(\mathrm{x}_{1}\right)$ & $\begin{array}{c}\text { Post-test } \\
\left(\mathbf{x}_{2}\right)\end{array}$ & Beda $(x)$ & $\mathbf{x}^{2}$ \\
\hline $\mathrm{Ki} 1$ & 11,5 & 5,5 & 6 & 36 \\
\hline $\mathrm{Ki} 2$ & 11,5 & 6,5 & 5 & 25 \\
\hline $\mathrm{Ki} 3$ & 9.5 & 4.5 & 5 & 25 \\
\hline $\mathrm{Ki} 4$ & 10,5 & 4,5 & 6 & 36 \\
\hline Ki 5 & 10,5 & 5,5 & 5 & 25 \\
\hline Ki 6 & 9,5 & 4,5 & 5 & 25 \\
\hline $\mathrm{Ki} 7$ & 9,5 & 5 & 4,5 & 20,25 \\
\hline $\mathrm{Ki} 8$ & 11,5 & 7,5 & 4 & 16 \\
\hline $\mathrm{Ki} 9$ & 11,5 & 4,5 & 7 & 49 \\
\hline $\mathrm{Ki} 10$ & 9.5 & 5 & 4,5 & 20.25 \\
\hline Ki 11 & 9,5 & 4,5 & 5 & 25 \\
\hline $\mathrm{Ki} 12$ & 10,5 & 5,5 & 5 & 25 \\
\hline Ki 13 & 10,5 & 4,5 & 6 & 36 \\
\hline Ki 14 & 9,5 & 4,5 & 5 & 25 \\
\hline Ki 15 & 11,5 & 6,5 & 5 & 25 \\
\hline $\mathrm{N}=15$ & $\Sigma x 1=156,5$ & $\Sigma \times 2=78,5$ & $\Sigma \mathrm{x}=78$ & $\Sigma \times 2=413,5$ \\
\hline T hitung & 11,02 & & $\mathrm{db}$ & 28 \\
\hline \multicolumn{4}{|c|}{ T Tabel } & 1,70 \\
\hline
\end{tabular}


Untuk melihat pengaruh senam nifas terhadap involusi uterus pada kedua kelompok pembanding, hasil pengukuran dianalisa dengan menggunakan rumus $t$-test. Dimana derjat $\alpha=0,05$ (95\% confidence level). Jika hasil t hitung > t tabel, maka Ho ditolak yang artinya ada pengaruh senam nifas terhadap involusi uterus pada ibu post partum primipara pervaginam hari pertama sampai hari ketiga. Dan sebaliknya, jika t hitung < t tabel maka Ho diterima yang berarti tidak ada pengaruh senam nifas terhadap involusi uterus pada ibu post partum pervaginam hari pertarna sampai hari ketiga.

Hasil penelitian menunjukkan bahwa involusi uterus pada kelompok ibu yang senam nifas lebih cepat daripada kelompok ibu yang tidak senam nifas. Dengan hasil yang diperoleh $\mathrm{t}$ hitung $=11,02$ dan d.b $=28$; maka t tabel $0,95=1,70$. Karena $t$ hitung $>$ dari t tabel $(11,02>1,70)$, maka dapat maka dapat disimpulkan bahwa Ho ditolak yang artinva ada pengaruh senam nifas terhadap involusi uterus pada ibu post partum primipara pervaginam hari pertama sampai hari ketiga

\section{Pembahasan}

Berdasarkan hasil penelitian mengenai pengaruh senam nifas terhadap involusi uterus pada ibu postpart pervaginam hari 1-3 di Klinik Bersalin Tutun Sehati Tanjung Morawa, didapat adanya perbedaan penurunan tinggi fundus uterus antara kelompok kontrol dan kelompok intervensi. Hal ini sesuai dengan penelitian dan teori yang mengatakan bahwa senam nifas bermanfaat untuk ibu post dibuktikan dari hasil penelitian yang diperoleh dari uji-t yaitu t hitung 11,02 $>\mathrm{t}$ tabel 1,70 yang artinya ada pengaruh senam nifas terhadap involusi uterus pada ibu post paitun, primipara pervaginam hari 1-3 di

Morawa.

Menurut Dewi (2011), senam nifas merupakan latihan jasmani yang berfungsi untuk mengembalikan kondisi kesehatan, umuk mempercepat penyembuhan, mencegah timbulnya komplikasi, memulihkan dan memperbaiki regangan pada otot-otot setelah kehamilan, terutama pada otot-otot bagian punggung, dasar panggul, dan perut.

Senam nifas mempunyai pengaruh yang bermakna terhadap penurunan tinggi fundus uteri, kontraksi uterus dan pengeluaran lochea pada ibu pasca salin hari I-III, dengan nilai masing-masing $\mathrm{p}=0,00$. Hal ini terjadi karena dengan melakukan senam nifas akan memperlancar aliran darah dan meningkatkan tonus otot-otot uterus, akibatnya proses autolysis menjadi lancar, kontraksi uterus menjadi lebih kuat dan pengeluaran lochea semakin cepat (Jurnal Kesehatan FORIKES, 2011).

Hasil penelitian ini juga didukung oleh Larson berupa survei secara acak tentang efek senam nifas pada 1003 wanita Amerika mengaku setelah mengikuti program senam nifas dengan latihan yang teratur mengalami pengerutan pada rahim yang lebih kuat, selain itu juga mengalami penurunan pada berat badan selama enam minggu setelah melahirkan. Dan dalam studi dari 1432 ibu nifas di Swedia yang melakukan senam nifas ditemukan bahwa mayoritas $71 \%$ wanita tersebut mengalami metabolisme tubuh yang lancar, dan pemulihan fisik yang lebih cepat (Larson, 2002).

Dalam waktu 12 jam, tinggi fundus mencapai kurang lebih $1 \mathrm{~cm}$ di atas umbilicus. Dalam beberapa hari kemudian, perubahan involusi berlangsung dengan cepat. Tinggi fundus uterus turun kia-kira $1-2 \mathrm{~cm}$, setiap 24 jam. Pada hari keenam pascapartum fundus normal akan berada di pertengahan antara umbilicus dan simfisis pubis. Uterus tidak bisa dipalpasi pada hari ke-9 pascapartum (Bobak, 2004).

Dari hasil penelitian ini, setelah ibu post partum melakukan senam nifas selama 3 hari dengan gerakan yang benar, rata-rata penurunan tinggi fundus uterus yaitu $5 \mathrm{~cm}$ per hari. Sedangkan penurunan tinggi fundus uterus pada ibu post partum yang tidak melakukan senam nifas rata-rata $2 \mathrm{~cm}$ per hari.

Dari data demografi diperoleh rata-rata umur responden pada kelompok intervensi dan kelompok kontrol mayoritas berumur 20-30 tahun yang berarti mayoritas, responden pada penelitian ini berada dalam usia reproduksi sehat.

Menurut WHO, usia reproduksi sehat dikenal dengan usia aman untuk kehamilan dan persalinan adalah umur 20-30 tahun, dimana kehamilan ibu dengan usia di bawah 20 tahun berpengaruh kepada kematangan fisik dan mental dalam menghadapi persalinan. Rahim dan panggul ibu seringkali belum tumbuh mencapai ukuran dewasa. Akibatnya diragukan kesehatan dan keselamatan janin dalam kandungan. Selain itu mental ibu belum cukup dewasa sehingga, sangat meragukan pada keterampilan perawatan diri ibu dan bayinya.

Usia hamil yang ideal bagi seorang wanita adalah antara umur 20-35 tahun, karena pada usia tersebut rahim sudah siap menerima kehamilan, mental juga sudah matang dan sudah mampu merawat sendiri bagi dan dirinya (Draper, 2001).

Dari segi paritas, keseluruhan responden berada pada kelompok ibu dengan paritas pertama atau golongan pertama $(100,0 \%)$. paritas adalah jumlah anak yang dilahirkan oleh seorang ibu baik yang hidup maupun mati. Jumlah anak mempengaruhi involusi rahim. Otot-otot yang terlalu, sering teregang maka keadaan semula setelah teregang mernerlukan waktu yang sangat lama. Involusi uterus bervariasi pada ibu pasca persalinan dan biasanya ibu yang paritasnya tinggi, proses involusinya menjadi lebih lambat. Hal inni dipengaruhi oleh keadaan uterusnya. Karena semakin sering hamil akan sering kali mengalami regangan (Ambarwati, 2009).

Dari segi suku, responden terbesar berada pada kelompok suku Jawa (75\%). Menurut Philip Kotler, banyak faktor yang mempongaruhi perilaku sesorang, salah satunya adalah faktor sosial dan kebudayaan. Suku termasuk bagian dari budaya yang tentunya akan mempengaruhi perilaku dalam menggunakan pelayanan kesehatan. Pada penelitian ini, responden terbesar merupakan suku Jawa. Suku Jawa 
dikenal sebagai salah satu suku yang masih memegang teguh adat istiadatnya namun tidak ada kebiasaan atau tindakan-tindakan yang bertentangan dengan kesehatan selama penelitian berlangsung.

Dari segi pendidikan, responden terbesar berada pada kelompok pendidikan SMA (62,5\%). Tingkat pendidikan merupakan jenjang dalam penyelesaian proses pembelajaran secara formal. Makin tinggi tingkat pendidikan seseorang diharapkan pengetahuan dan perilakunya juga semakin baik. Karena dengan pendidikan yang makin tinggi, maka informasi dan pengetahuan yang diperoleh juga semakin banyak, sehingga perubahan perilaku ke arah yang lebih baik diharapkan dapat terjadi (Suryani, 2007).

Tingkat pendidikan sangat berpengaruh sejak proses kehamilan sampai dengan proses persalinan. Ibu yang berpendidikan tinggi cenderung untuk menikah pada usia yang matur di atas 20 tahun, pendidikan yang semakin tinggi menyebabkan kemampuan ibu dalam mengatur jarak kehamilan, jumlah anak, dan persalinan. Pada penelitian ini, responden terbesar merupakan tamatan SMA $(62,5 \%)$ sehingga pengetahuan tentang kehamilan dan melahirkan sudah cukup memadai walaupun masih kurang bila ditinjau dari paritas yang rata-rata merupakan kelahiran anak pertama (primipara).

Sedangkan bila ditinjau dari segi pekerjaan, responden terbesar berada pada ibu yang tidak bekerja atau ibu rumah tangga (56,25\%). Pekerjaan seorang ibu bisa mempengaruhi kondisi dari kehamilan. Ibu dengan pekerjaan yang berat dapat mempengaruhi kondisi janin, uterus dan organ reproduksi lainnya. Hal ini dapat menyebabkan perubahan letak daripada janin dalam kandungan dan juga bahaya lainnya yang merupakan komplikasi dari kehamilan. Namun pada penelitian ini, responden rata-rata merupakan ibu rumah tangga sehingga tidak ditemukan komplikasi selama hamil dan melahirkan.

Pada penelitian ini banyak keterbatasan peneliti, secara teori penurunan tinggi fundus uterus tidak hanya dipengavuhi oleh senam nifas saja akan tetapi banyak faktor lain yang sangat memegang peranan penting dalam penurunan tinggi fundus uterus. Faktor-faktor lain tersebut yaitu status gizi/nutrisi, menyusui (Hulu, 2012). Yang mana faktor tersebut tidak diteliti/tidak dilakukan analisa, selain itu gerakan nifas tidak disederhanakan sehingga peneliti harus mengulang 2-3 kali pada saat mengajarkan senam.

\section{KESIMPULAN DAN SARAN}

\section{Kesimpulan}

1. lbu post partum pervaginam yang tidak senam nifas pada hari 1-3 mengalami penuranan tinggi fundus uterus rata-rata $2 \mathrm{~cm}$.Ibu post partum yang senam nifas dengan gerakan yang tepat pada hari 1-3 mengalami penurunan $5 \mathrm{~cm}$.

2. Pengaruh senam nifas terhadap involusi uterus didapat hasil t hitung 11,02 > t tabel 1,70 yang menunjukkan bahwa adanya pengaruh senair, nafas terhadap involusi uterus

\section{Saran}

1. Agar Klinik Bersalin Tutun Sehati Tanjung Morawa dapat menerapkan dan memberikan motivasi kepada ibu-ibu post partum untuk melaksanakan senam nifas yang bermanfaat bagi ibu sendiri di dalam proses pemulihan diri pasca partum.

2. Agar hasil penelitian ini dapat menjadi informasi dan bahan masukan bagi institusi pendidikan dan profesi keperawatan khususnya mata kuliah keperawatan maturnitas dimana dengan senam nifas dapat mempercepat involusi uterus pada ibu post partum.

3. Bagi peneliti selanjutnya agar dapat melanjutkan penelitian tentang pengaruh senam. nifas terhadap involusi uterus pada ibu post partum pervaginam, menambah jumlah sampel penelitian dan waktu penelitian yang lebih lama.

\section{DAFTAR PUSTAKA}

Ambarwati, R. \&. (2009). Asuhan Kebidanan Nifas. Yogyakarta: Mitra Cendekia Press

Anggraini, Y. (2010). Asuhan Kebidanan Masa Nifas. Yogyakarta: Pustaka ID Rihama.

Arikunto. (2010). Prosedur Penelitian. Jakarta: Rineka Cipta.

Biro Pusat Statistik. 2003. Survei Demografi dan Kesehatan 2003. Jakarta: Depkes RI.

Bobak. (2004). Buku Ajar Keperawatan Maernitas. Jakarta: EGC.

Cunningham, F. G. (2005). Obstetri Williams. Jakarta: EGC.

Dewi, V. N. (2011). Asuhan Kebidanan pada Ibu Nifas. Jakarta: Salemba Medika.

Huliana, M. (2003). Perawatan Ibu Pasca Melahirkan. Jakarta: Puspa Swara.

Hulu, R. (2012). Pengaruh Menyusui terhadap Percepatan Penurunan Tinggi Fundus Uteri pada Ibu Post Partum Hari Pertama dan Kedua di Klinik Ernawati Pancur Batu Medan Tahun 2012. Skripsi. Medan: Sekolah Tinggi Ilmu Kesehatan Sumatura Utara.

Indonesia, T. C. (2011). Penduduk Dunia 7 Milyar, Sebuah Krisis yang Mengancam. [Online]. Dari

https://mediaanakIndonesia.wordpress.com/20 11/20 12/penduduk-dunia-7- milyar-sebuahkrisis-yang-mengancam/. [Diakses pada tanggal 7 November 2011

Kasjono, H. S., \& Yasril. (2009). Teknik Sampling untuk Penelitian Kesehatan. Yogyakarta: Graha Ilmu.

Notoatmodjo, S. (2002). Metodologi Penelitian Kesehatan. Jakarta: Rineka Cipta.

Nursalam. (2003). Konsep Dan Penerapan Metodologi Penelitian Ilmu Keperawatan. Jakarta: 
Salemba Medika.

Prawirohardjo, S. (2006). Ilmu Kebidanan. Jakarta: Yayasan Bina Pustaka Sarwono Prawirohardjo.

Pusdiknakes-WHO-JHPIEGO. 2003. Asuhan Kebidanan Post Partum. Buku 4. Jakarta

Purwaningrum, Y. (2011). Pengaruh senam Nifas terhadap Kecepatan Penurunan Tinggi Fundus Uteri padaA Ibu Post Partum Primipara Hari Pertarna sampai Hari Ke Lima di Puskesmas Mergangsan. Jurnal Penelitian Kesehatan Suara Forikes 20863098.

Dari:http://suaraforikes.webs.com/volum2/no morkhusus-HKN.pdt [Diakses: 7 Desember 2012].

Roito, J. (2010). Asuhan Kebidanan Thu Nifas. Jakarta: 2010. Rustam. (1998). Sinopsis Obstetri. Jakarta: EGC.

Saleha. (2009). Asuhan Kebidanan pada Masa Nifas. Jakarta: EGC.

Suherni, W.d. (2009). Perawatan Masa Nifas. Jakarta. EGC

Sulistyawati, A. (2009). Baku Ajar Asuhan Kebidanan pada Ibu Nifas. Jakarta: Andi.

Sunarsih, V. d. (2011). Asuhan Kebidanan pada Ibu Nifas. Jakarta: Salemba Medika.

Toyibah, A. 2003. Pengaruh Senam Nifas Terhadap
Percepatan Turunnya Fundus Uteri Pada Hari PeRTama Pasca Salin di Ruang BerSalin

II Dr. Soetomo Surabaya. Skripsi. Surabaya, Dari://http:www.googlescholars.com.

[Diakses: 11 Januari 20131.

Varney, H. (2004). Buku Ajar Asuhan Kebidanan Edisi 4 Volume 2. Jakarta: EGC.

Widianti. (2010). Asuhan Kebidanan Masa Nifas. Jakarta: EGC.

Wiknjosastro, H. (2005). Ilmu Bedah Kebidanan. Jakarta: Yayasan Bina Pustaka.

Sarwono Prawiroharjo. Yustanto, T. J. (2008). Senam Nifas terhadap Involusi Uteri. Jurnal Kesehatan, 113-118.

Darihttp://publikasi.umy.ac.id/index.php/psik/articic /vicwfiles/113-118 [Diakses: 6 November 2012]S. Sibuea, 2008. Hubungan Pemanfaatan Bidan dengan Cakupan Program, Jakarta

Notoatmodjo Soekidjo, 2002, Metode Penelitian Kesehatan. Rineka Cipta, Jakarta , 2010, Metode Penelitian Untuk Kedokteran dan Kesehatan, Jakarta

Wiknjosastro Hanafi, 2005, Ilmu Kebidanan, Yayasan Bina Pustaka, YogyakartA

2009, Ilmu Kebidanan, Yayasan Bina Pustaka, Yogyakarta 